\title{
Based on the Theory of Optimizing the Allocation of Research of Sustainable Utilization of Water Resources of the Upper Reaches of Minjiang River
}

\author{
Canyuan Liu \\ Southwest University for Nationalities, Chengdu, China \\ Email: 272411722@qq.com
}

How to cite this paper: Liu, C.Y. (2020) Based on the Theory of Optimizing the Allocation of Research of Sustainable Utilization of Water Resources of the Upper Reaches of Minjiang River. Natural Resources, 11, 473-498.

https://doi.org/10.4236/nr.2020.1110028

Received: September 11, 2020

Accepted: October 23, 2020

Published: October 26, 2020

Copyright ( 2020 by author(s) and Scientific Research Publishing Inc. This work is licensed under the Creative Commons Attribution International License (CC BY 4.0).

http://creativecommons.org/licenses/by/4.0/

\section{(c) (i) Open Access}

\begin{abstract}
Water resource is an important supporting material for life support system and economic development, and the sustainable development and utilization of water resource are the guarantee of social sustainable development. The upper Minjiang River is the most important source of water supply for the Chengdu Plain. With the water resources of the upper Minjiang River facing the problems of overall water volume reduction, flood and water pollution, etc., based on the optimal allocation theory, this paper constructs an optimal allocation model of water resources in the upper reaches of the Minjiang River, analyzes its characteristics and proposes some relevant countermeasures and suggestions to solve the existing problems, aiming to provide references for the sustainable utilization of water resources in the upper reaches of the Minjiang River.
\end{abstract}

\section{Keywords}

The Upper Reaches of Minjiang River, Water Resources, Optimized Configuration

\section{Analysis of Natural Environmental Conditions and Water Resource System Characteristics in the Upper Minjiang River Basin}

\subsection{Natural Environmental Conditions of the Upper Minjiang River Basin}

\subsubsection{Geographical Overview}

The upper reaches of Minjiang River are located in the eastern region of Qing- 
hai-Tibet Plateau, the northwest of Sichuan Basin and the east of Aba Autonomous Prefecture. They are located in the triangular block between the Qinling zonal tectonic belt, the NE Longmenshan tectonic belt and the NW Malkang tectonic belt, between the east longitude of $102^{\circ} 33^{\prime} 46^{\prime \prime}-104^{\circ} 15^{\prime} 36^{\prime \prime}$ and the north latitude of $30^{\circ} 45^{\prime} 37^{\prime \prime}-33^{\circ} 69^{\prime} 35^{\prime \prime}$. The area is a part of Aba Tibetan and Qiang Autonomous Prefecture, including Wenchuan, Li county, MAO County, Songpan county and Heishui County, covering a total area of 25,426.875 square kilometers, Beichuan, An County, Mianzhu border in the east, South of Zuoqing, Dayi, hongyuan, Markang in the west, jiuzhaigou County, Ruoergai county border in the north.

\subsubsection{Geological Landforms}

Most of the terrain of the upper Minjiang River belongs to the Minjiang Mountain range, and the southeast border belongs to the tail section of Longmen Mountain. It slopes from the northwest to the southeast, with the highest altitude of 6250 meters (Sigungshan mountain) and the lowest altitude of 780 meters (the Southeastern Xuankou area). According to the unified classification of geomorphic types in Sichuan Province, the upper reaches of Minjiang River can be divided into four basic types: low Zhongshan 1108.6 square kilometers, high Zhongshan 18,205.6 square kilometers, high mountain 5415.9 square kilometers, and high mountain 737.9 square kilometers. Most of the geology in the area belongs to the Markang and Longmenshan geological zones, and belongs to the zonal tectonic system. Metamorphic rocks, such as schist, phyllite, sand SLATE, marble and so on, are mainly distributed in the area. The terrain of this area is basically presented according to the pattern of plane-inclined valley anticlinal mountain. The terrain slopes towards the southeast Sichuan basin, present typical alpine canyon landform.

In terms of the overall landform of the area flowing through the upper reaches of the Minjiang River, the three-level landform has the obvious segmentation structure. The First-level Hanchuan-Maoxian section has narrow "U-shaped" valley geomorphologic feature, the second-level Maoxian-Songpan section has $\mathrm{v}$-shaped alpine gorge feature, and the third-level Songpan-Gonggaaling section has u-shaped valley feature.

\subsubsection{Climatic Conditions}

The upper reaches of the Minjiang River have a monsoon climate, with dry air and low temperature. Due to the great difference of altitude difference and complicated terrain, the climatic difference in the region is significant and has the climatic characteristics of mountain standing. The year-round sunshine duration of the area is $1500-1800$ hours, and the sunshine percentage is $38 \%$. The average annual temperature in this area is $10.2^{\circ} \mathrm{C}$, the average annual precipitation is $724.9 \mathrm{~mm}$, the highest annual precipitation is $1190.9 \mathrm{~mm}$, the lowest $492.7 \mathrm{~mm}$.

The dry and wet seasons in the upper reaches of the Minjiang River are obvious, and the rainy season is longer, which is from May to October each year, 
while the dry season is less, which is from November to April of the following year. The average temperature of dry season, rainy season and annual decreased with the increase of altitude, and there was no significant difference in the recurrence rate of temperature, showing typical vertical distribution characteristics of climate. In the upper part of the dry and warm river valley of the upper Minjiang River, the most month is December every year, while in the lower part of Maoxian County, the most month is August every year, and the rate of change is relatively small. The annual evaporation is only $1332 \mathrm{~mm}$, and the annual precipitation is only $493 \mathrm{~mm}$.

According to the above analysis, the upper reaches of the Minjiang River are characterized by significant vertical zonation due to the vast territory, high mountains and deep valleys with distinct vertical terrain differentiation, and very obvious climatic differences. The geographical location, geomorphic background, ecological and climatic conditions of the upper Minjiang River water source area and other natural environmental conditions.

\subsection{Analysis of the Characteristics of Water Resources System in the Upper Minjiang River Region}

\subsubsection{River System Characteristics}

As a major tributary of the Upper Reaches of the Yangtze River, Minjiang River originates from the southern foot of Minshan Mountain at the junction of Sichuan and Gansu. It is divided into east and west sources, with its east source starting from Lungangling and the Zhangjin River flowing through Zhangla. The west source starts from Langiialing, which is Yangdong River flowing through Huangshengguan. The two rivers converge at Hongqiao Pass of Songpan Yuanba Township and travel southward along The Minshan Mountains. The main stream flows from north to south from Songpan and enters Chengdu Plain via Maoxian county, Wenchuan and Dujiangyan, presenting an asymmetrical dendry-shaped water system. The average ratio drops by $8.2 \%$, and the average annual flow at the exit is $452 \mathrm{~m}^{3} / \mathrm{s}$. The first level tributary is Heishui River (Tibetan cuoqu), which originates from Xiniang Mountain, crosses Heishui county, passes the Lianghekou of Maoxian County, and enters Minjiang River. The rivers belonging to this tributary are Maergai River, XiaoHeishui River and Chiwusu River. The other tributary of the first grade is The Zegatuo River (Tuo River in history), which originates from the side of The Partridge Mountain and flows into the Minjiang River in Weizhou Town via Miyara, Zegatuo, Xuecheng, Longxi and other places. The river of this tributary is the Mendong River. Another tributary is Yuzixi (also known as Erhe), which originates from the eastern slope of Balang Mountain in the southwest of Wolong, Wenchuan, and falls into the Minjiang River at Yingxiu Zhongtanpu.

\subsubsection{Characteristics of Surface Water and Groundwater Resource System in the Basin}

1) The basic situation and characteristics of surface water resources in the ba- 
$\sin$

The water resources in the upper reaches of Minjiang River mainly meet the needs of domestic and production water runoff. The characteristics of water resources in the upper reaches of Minjiang River are mainly reflected in the temporal and spatial distribution and actual changes of runoff. According to years of hydrological measurement data, the variation of river discharge in the upper Minjiang River basin shows an obvious annual cycle, but the variation of annual discharge is not repetitive. Therefore, various characteristic values such as annual maximum, minimum and average runoff as well as the runoff in different periods of the same period can be studied as random phenomena. The long-term average runoff is an important characteristic value of water resources scale in the upper reaches of Minjiang River.

The annual precipitation of the upper Minjiang River is $494.8-1332.2 \mathrm{~mm}$, which is not evenly distributed in time and space. In the upper reaches of the Minjiang River, there are distinct wet and dry seasons [1]. From May to October, the rainy season accounts for more than $80 \%$ of the rainfall, while from November to April of the following year, the dry season accounts for only about $20 \%$ of the rainfall. The available water resources of the five counties in the upper reaches of the Minjiang River vary greatly, with MAO County being the smallest, Followed by Heishui County, Wenchuan County, Li County, and Songpan County being the largest (see Table 1). The precipitation in the upper reaches of Minjiang River is relatively large and the runoff from melted snow is an important part of water resources in this area.

The quality of water resources in the upper reaches of Minjiang River should be attached great importance to as the drinking water source and basic farmland irrigation water in Chengdu Plain. A total of 26 surface water quality monitoring sections (national control and provincial control) were set up in the Minjiang River basin to collect data for analysis by the Sichuan Provincial Environmental monitoring Center. Statistical analysis shows that the basin of the upper reaches of Minjiang river water quality, reach I class water quality standard, conform to the whole basin II class water quality standard, medium above basins in China belong to the water quality good [2].

Table 1. Annual average available water resources of the upper Minjiang River area.

\begin{tabular}{cccccccccc}
\hline & & \multicolumn{2}{c}{$\begin{array}{c}\text { Statistical parameters } \\
\text { of surface water resources }\end{array}$} & \multicolumn{3}{c}{$\begin{array}{c}\text { Design value of surface } \\
\text { water resource quantity }\end{array}$} \\
\cline { 3 - 8 } & Mean value & $\mathrm{Cv}$ & $\mathrm{Cs}$ & $\mathrm{p}=20 \%$ & $\mathrm{p}=50 \%$ & $\mathrm{p}=75 \%$ & $\mathrm{p}=95 \%$ \\
\hline & Wenchuan & 30.94 & 0.13 & 0.25 & 35.08 & 30.59 & 27.36 & 23.27 \\
& Lixian & 31.81 & 0.09 & 0.19 & 34.74 & 31.63 & 29.30 & 26.26 \\
& Maoxian & 20.23 & 0.10 & 0.21 & 22.32 & 20.11 & 18.45 & 16.29 \\
& Songpan & 46.78 & 0.10 & 0.20 & 52.63 & 46.28 & 41.72 & 35.96 \\
\hline
\end{tabular}

Source: Aba Water Authority. 
Basin surface water resources characteristics: according to the measured data, the dujiangyan hydrological stations in recent decades, the amount of the upper reaches of Minjiang river, on the whole, is on the decline, but from the point of total water resources, region of the upper reaches of Minjiang river water resources amount is larger, river most through deep valleys, rivers, big difference, the uneven distribution of water years, precipitation spatial distribution. Therefore, the water resources in the upper Minjiang River basin are characterized by abundant water, uneven spatial and temporal distribution and poor storage.

2) Basic situation and characteristics of groundwater resource system

Water resources, such as rivers, lakes, Wells, springs and tides, are indispensable natural resources for the development of national economy, and are also the basic conditions for human survival, reproduction and development. In the upper reaches of the Minjiang River, groundwater can be divided into fissure water, pore water and karst water.

Regional inland water is mostly weak acid drinking water, individual is hard water, and mostly colorless, tasteless. Its water resource types are as follows:

1) Pore water

Pore water is mainly distributed in the Hongyuan-Ruoergai grassland area in the north of the plateau, and its enrichment degree is affected by the composition, thickness and structure of the accumulation material.

2) The fissure water

The metamorphic rocks are widely distributed in the region, so most of the fissure water is metamorphic rocks. Fissure water is mainly supplied by meteoric water and meltwater from snow and ice, and the runoff path is not long. It is usually discharged in the form of spring in the slope-foot gully and fault zone in the low-lying areas.

\section{3) Karst water}

Mainly distributed in songpan edge: Jiuzhaigou area. The water-bearing rocks are mainly carbonate rocks of Devonian, lithocarbon, Permian and Lower Triassic

Water resources in the upper Minjiang River have the following characteristics: The time distribution of resources is uneven, with obvious seasonality About $80 \%$ of the annual precipitation is concentrated in the sixth, seventh, eighth and ninth months of each year, while the water consumption is the highest in the fourth, fifth and sixth months. At this time, the precipitation is significantly low, accounting for only $20 \%$ of the total precipitation. In addition, the long dry season, runoff and flood discharge, the effective use of water resources has not been guaranteed, so in time can not achieve the balance of water.

The distribution of water resources has obvious regional characteristics

As can be seen from the remote sensing map of water resources in the upper reaches of the Minjiang River, the plain area is rich in water resources, while the hilly area has relatively less water resources, while in the alpine area, the water is mostly springs flowing. According to the water Resources Bulletin of the Water Resources Department of Sichuan Province, most of the water in the upper 
Reaches of the Minjiang River comes from groundwater, especially in mountainous areas, accounting for nearly two-thirds of the total water resources in the administrative area of the upper reaches of the Minjiang River.

The total amount of water resources has a significant reduction trend

In recent years, due to the deterioration of the ecological environment and the low precipitation, the water resources in the upper reaches of Minjiang River also show a decreasing trend to different degrees. The main reasons are the decrease of the water resources in the river and the continuous decrease of the water resources reserves in groundwater. Because there is no regulating reservoir in the main stream of Minjiang River, the upper reaches of the forest are seriously damaged, and the water volume in the flood period can hardly be utilized, and most of it flows away, causing floods. Therefore, the actual available water volume of Minjiang river is only about 6 billion cubic meters per year.

\subsubsection{Impacts of Human Activities on Water Resources and Ecological Environment in the Basin}

1) Low level of comprehensive utilization of water resources and prominent contradiction between supply and demand in dry season

The lack of unified management of water resources in the upper reaches of Minjiang River and the lack of supporting water conservancy and hydropower projects make it difficult to give full play to the utilization benefits of water resources. It is difficult to carry out effective unified management between agriculture and industry, production and domestic water and water source projects, each goes its own way and is independent [3]. Hydropower stations of various sizes in the main and tributaries along the way are scattered and blooming everywhere. Moreover, most of them are runoff diversion power stations, which results in the dry reach of the river and the cut off flow, seriously affecting aquatic organisms. Generally, the flood control (water storage) function of each hydropower station is not considered enough and the function is single in the development process. From the economic analysis of water resources, if the water resources in the upper reaches of Minjiang River can achieve a larger water supply and demand balance under a very low water price (almost free use) for a long time, it will inevitably accelerate the arrival of water resources crisis. Due to the misplacement and utilization of water resources, the economic water in the dry season occupies the ecological water, and the problem of irrigated agriculture in spring and drought is prominent, which seriously restricts the land use and agricultural production.

2) There are serious environmental problems in urban and rural areas and serious industrial and agricultural pollution

The economic development of the upper Reaches of The Minjiang River is relatively backward, the urban infrastructure is seriously backward, and the urbanization process is slow. Due to the narrow topography, the effective use of land and the limited scale expansion of cities and towns, the spatial distribution of population and industry is scattered, and it is difficult for public facilities, in- 
frastructure and service supply to form scale effect. Some counties and market towns in this area have no garbage and sewage treatment facilities, and the earthquake has made some environmental protection enterprises unable to operate normally. During holidays, the number of tourists in scenic spots has soared, leading to pollution of the scenic environment and water bodies. The discharge of industrial wastes is very serious, and some high-load energy enterprises with primitive equipment and backward technology have become large polluters. Pollution from agricultural production wastes and livestock and poultry breeding is worsening, and pollution from point and non-point sources is increasing.

3) With the increasing number of sensitive areas, the ecological environment is more fragile

The upper Minjiang River region was originally a kind of typical fragile ecosystem based on the arid valley, which was the result of the interaction of primary vulnerability caused by the local special climatic conditions, geological and geomorphic conditions as the basement, and secondary vulnerability caused by the stress of human activities. After the earthquake, the evolution of ecological environment in the upper Minjiang River region was accelerated from low vulnerability to high vulnerability over time. The areas of extremely sensitive and highly sensitive areas were enlarged, the factors of ecological instability increased, and both structural and stress vulnerability were increased.

4) Forest receded soil erosion, serious ecological function degradation

After large-scale deforestation in the upper reaches of the Minjiang River, the forest resources have been greatly reduced, the forest age structure is poor, the forest environment is degraded and the forest biodiversity is reduced, especially the sharp reduction of the original forest trees, resulting in the rapid decline of water conservation capacity and plant and animal species in the upper reaches. The geological changes and secondary disasters caused by the big earthquake have exposed mountains in this area, blocked river channels, gradually expanded arid valleys, reduced river runoff (the number and time of interruption increased), intensified hydrological changes, increased soil erosion, decreased land fertility, and increasingly degraded ecological functions.

5) The ecological grassland worsened due to the disaster of overgrazing rats and insects

Grassland in the upper reaches of Minjiang River is still in the state of relying on nature to raise livestock and natural grazing. Due to the infestation of rats and worms and human destruction, medicinal materials are randomly collected and dug. The usable area of grassland is reduced, the invasion of different grass species and poisonous weeds, the distribution of fine grass species is reduced, the grassland fertility is weakened and the regeneration ability is reduced. At the same time, overgrazing, overgrazing and unreasonable herd structure aggravated the dysfunction of grassland ecosystem, aggravated the obvious deterioration of grassland environment, and made grassland degradation and desertification very 
common and alarming.

\subsubsection{Problems Existing in the Utilization of Water Resources in the Basin}

1) Lack of unified management of relevant departments

The lack of unified management of water resources in the basin and the lack of supporting water conservancy and hydropower projects make it difficult to give full play to the utilization benefits of water resources. It is difficult to carry out effective unified management between agriculture and industry, production and domestic water and water source projects, each goes its own way and is independent.

2) Lack of scientific management of hydropower enterprises

Hydropower stations of various sizes in the main and tributaries along the way are scattered and blooming everywhere. Moreover, most of them are runoff diversion power stations, which results in the dry reach of the river and the cut off flow, seriously affecting aquatic organisms.

3) Prominent contradiction between supply and demand in dry season

From the economic analysis of water resources, if the water resources in the upper reaches of Minjiang River can achieve a larger water supply and demand balance under a very low water price (almost free use) for a long time, it will inevitably accelerate the arrival of water resources crisis. Due to the misplacement and utilization of water resources, the economic water in the dry season occupies the ecological water, and the problem of irrigated agriculture in spring and drought is prominent, which seriously restricts the land use and agricultural production.

4) Weak legal construction of water resources and environmental protection

At present, China has promulgated and implemented the Water Law, Flood Prevention Law, Water Pollution Prevention And Control Law, Soil and Water Conservation Law and other laws, and established a relatively complete system of water laws and regulations, and there are laws to be followed in water resource management. However, in terms of water resources management in China, the laws and regulations promulgated by different departments in different periods are in conflict with each other, resulting in confusion and unclear ownership of water resources management, thus weakening the intensity of water resources management. In addition, although the water Law has been revised, the existing water resources legal system is not perfect. To date, there has not been a unified water resources Management Law. Due to the limitation of cognition and the difference of economic development level, the public's concept of environmental legal system is relatively weak.

\subsubsection{Research Idea}

According to the regional geological conditions and river system characteristics of the upper reaches of Minjiang River, the sustainable development and utilization of water resources should be put in the first place.

On the basis of fully absorbing the opinions of experts and professors, the re- 
search data, calculation methods, calculation models and research results of this paper are comprehensively modified and sorted out, so as to ensure the effectiveness and accuracy of the research and achieve the purpose of sustainable development and utilization. In addition, with the application of relevant principles and scientific methods such as water resources development science, hydrogeology, optimal allocation theory of water resources and the combination of field investigation and indoor analysis, and the reference of some beneficial experience and achievements of predecessors at home and abroad, the preliminary research steps of water resources in the upper reaches of Minjiang River are as follows:

1) Domestic and foreign literature query, reading, and data collection; domestic specific requirements of the project to preliminarily lock the research objects.

2) Based on the regional geological survey method, carry out field survey, data collection and work summary of rivers in the upper Minjiang River and counties, cities and districts around Chengdu, focus problems and determine research objects and objectives.

3) Analysis and data comparison of typical water resources in the upper reaches of Minjiang River, analysis of optimal allocation methods of water resources and establishment of optimal allocation model.

4) Based on the case study of optimal allocation of water resources in the upper reaches of Minjiang River, Suggestions and countermeasures for sustainable utilization guarantee are put forward [4].

\section{Establishment and Scheme Analysis of Optimal Allocation Model of Water Resources in the Upper Minjiang River Basin}

\subsection{Methods for Optimal Allocation of Water Resources in the Upper Minjiang River Basin}

The optimal allocation of water resources in the basin adopts the method of combining macro analysis and micro analysis to maintain the sustainable utilization of water resources by restraining water demand, controlling total water consumption, limiting pollutant discharge and improving water efficiency. Specifically, it is in general social economy and the appropriate proportion of water ecological environment, by building water conservancy projects, the natural water process adjustment to meet or close to meet the social, economic and ecological water requirement process, to achieve the balance between the supply and demand of water resources, and according to the water quality target and environmental carrying capacity, water function area of pollutant total amount control. Water conservancy project is the control hub of water resources allocation, which distributes the limited water resources to different water departments through regulation and control.

\subsubsection{Characteristics of Optimal Allocation of Water Resources}

The characteristics of water resources include the quantity and quality of water. 
In the early stage of urbanization and industrialization, the allocation of water resources in the river basin was mainly focused on water allocation. In this stage, the scale of social and economic water use is small, the water pollution is not serious, the river water quantity is relatively rich, the self-purification ability of the water body generally maintains good water quality, and the allocation of water resources based on water quantity basically meets the water requirements of social economy and ecological environment. With the rapid increase of water use in social economy and the aggravation of water pollution, the quality problem of water resources has become prominent, and the social economy and ecological environment have put forward the dual requirements of quality and quantity of water resources. In the face of the current shortage of water resources, it is necessary to maintain the reasonable proportion of water consumption between social economy and ecological environment in quantity, maintain the sustainable utilization of water resources, reduce the pollutant load into water bodies, and improve the quality of water resources.

Water resource system, social economic system and ecological environment system are interdependent and mutually restricted. The health of ecological environment is the basis for ensuring the rapid development of social economy and improving human habitat. As the most active environmental factor, water organically links the two as a whole. The water used in ecological environment has great elasticity. Within a certain proportion of water, the self-repairing ability of ecological environment system is strong, and it basically keeps dynamic balance with the social and economic system. When the proportion of water used in the ecological environment is less than a certain threshold, the ecological environment system will be destroyed and become rigid and unrecoverable, leading to a decrease in the amount of available water resources, which in turn will restrict the development of social economy. The optimal allocation of water resources in the basin tries to coordinate the dynamic interdependence of water resources system, social economic system and ecological environment system from the aspects of water resources quality and quantity, especially the mutual restriction relationship between them, so as to comprehensively utilize the limited water resources.

\subsubsection{Multi-Objective Decision Analysis and Optimization Simulation Method}

The objective of optimal allocation of water resources in the basin is to coordinate the relationship between social economy and ecological environment on the premise of maintaining the regeneration mechanism and sustainable utilization of water resources, rationally allocate the limited inter-regional water resources, meet the water quality goals of water function areas, and promote the healthy development of social economy and ecological environment.

1) Multi-objective decision analysis

River basin water resources optimal allocation following the sustainability, equity, efficiency and total amount control, such as systematic principle, regula- 
tion relating to sustainable utilization of water resources, ecological and social decision-making problem, the decision problem is interconnected and contradict each other, and the content of the economy, environment and so on, is a multi-objective decision problem, the decision problem is interconnected and contradictory, configuration achievement is the result of game between each target to compromise. Operations research is the effective tool to solve the problem of multi-objective decision making, can be water resources system, the social economic system and ecological system as an organic whole, and index as the objective function or constraint equations, the objective function maximum (or minimum) cases, through repeated iteration to solve the optimal values of the decision vector, as a social economic system and the ecological environment system of water resource demand reference. The general mathematical expression of multi-objective problems is:

$$
\max (\min ) Z=\left\{f_{1}(\bar{x}), f_{2}(\bar{x}), \cdots, f_{n}(\bar{x})\right\}^{T}
$$

s.t. $\bar{x} \in S$

In the formula, $\bar{x} \in R^{n}$, is a vector composed of decision variables, and $R$ is a set of n-dimensional real vectors; Is the objective function, which represents the main development objectives in social economy, ecological environment and water resources respectively, and is a set of measures to measure the merits and demerits of an optimal water resource allocation scheme. $S$ is the feasible region of the decision vector, which is composed of various constraints.

2) Optimize the simulation method

At present, the water resources allocation is usually simulated by the so-called rule model and optimization model. The rule model and the optimization model are essentially the same, but the calculation method is different.

The rule model is guided by a certain rule set. Count from upstream to downstream. The water objects at the section nodes are allocated according to the rules or the proportion of water allocation made in advance, and then adjusted repeatedly from upstream to downstream for many times. The results of the overall basin configuration have a great deal to do with the experience of the computor. Advantages: clear concept, flexible, easy to understand, in line with traditional thinking habits. Cons: More reliance on computor experience.

\subsection{Establishment of Optimal Allocation Model of Water Resources in the Upper Minjiang River Basin}

\subsubsection{Idea of Model System Construction}

River basin water resources optimal allocation model of system using system analysis method, from the research area of the upper reaches of Minjiang river water quantity, water quality and water ecology, water environment with water relationship, in the full absorption of water resources allocation on the basis of research achievements at home and abroad, combined with the existing work accumulation, water resources, social economy and ecological environment system as an organic whole, through the reasonable deployment of basin in propor- 
tion to the social and economic water consumption and water ecological environment, coordination and alleviate the competition of the social economy and ecological environment in the use of water. On the basis of maintaining the sustainable use of regional water resources, we should strengthen demand management and strict pollution reduction measures, and use water conservancy projects as a link to distribute the limited water resources to all water users in a fair and efficient way, so as to promote the healthy development of regional social economy and ecological environment [5].

River basin water resources optimal allocation model of system construction, in order to "five-year", and " 15 " of the ninth five-year plan put forward by the national science and technology research based on the optimized allocation of water resources, water resources of macroeconomic dual dynamic cycle of natural and artificial evolution pattern, the optimized allocation of water resources for ecological countermeasures and key support technology research and the major environmental problems, and river basin water resources optimal allocation model research results as the foundation, the water resources system is decomposed into the natural and artificial collateral circulation system, centered on river basin water resources partition constitute water balance analysis of water resources system, centered on the cell balance analysis of supply and demand of water resources system, The river system is the core of the groundwater simulation system based on optimal allocation of water resources, the shallow groundwater in the plain area is the core of the water consumption balance analysis system, and the shallow groundwater in the plain area is the core of the groundwater numerical simulation system [6]. The water resource consumption balance analysis system is the scientific basis for controlling and allocating the proportion between social and economic water consumption and ecological water consumption in the water resources division of the basin, and is also the basic control unit for parameter calibration of the model of optimal allocation of water resources.

The parameter calibration of the configuration model takes the selected minimum water resource partition as the control precision [7]. The water quality type of each control node is determined by the water supply and demand balance analysis system and the water quality simulation model system based on the optimal allocation of water resources through mutual iteration. The water supply and demand balance analysis system of water resources supplies water to water users according to the water quality types of nodes, and analyzes and estimates the water quality status of river water functional areas based on the water quality simulation model of optimal allocation of water resources. The groundwater numerical simulation system provides the upper limit of groundwater recoverable and water quality status in plain area for the water resources supply and demand balance analysis system [8].

If in water resources optimal allocation results, water shortage is very serious, river water quality in water function areas have not reached planning target, is 
proposed according to the results of water quality simulation computing unit of point source and non-point source pollutants reduction plan and sewage emission reduction measures, through repeated iteration, adjustment, eventually meet the social and economic water use and water quality goals. For the calculation results of the proposed water resources optimal allocation scheme set, the evaluation method of water resources optimal allocation scheme was used for comprehensive evaluation, and the feasible water resources optimal allocation scheme was recommended.

\subsubsection{Model System for Optimal Allocation of Water Resources}

System for water resources optimal allocation model of water resources of natural and artificial evolution binary collateral circulation patterns as the foundation, by supply and demand balance analysis system and water balance analysis system, its core content is reasonable control and allocate water ratio, the social and economic water consumption and ecological environment in water conservancy projects as the link will be fair and efficient water resources allocated to each water user, coordination and alleviate the competition of the social economy and ecological environment in the use of water [9]. Water resources survey and evaluation, evaluation and utilization of water resources, water demand forecasting, water conservation, water conservation, water supply forecast is the basis of the optimal allocation of water resources, such as supply and demand balance analysis and calculation based on the cell and the corresponding node, water transmission system, water balance analysis and calculation based on basin water resource partitioning and its water transmission system.

The optimal allocation of water resources involves water resources system, social economic system and ecological environment system, and the network diagram of water resources allocation system is a simplification and abstraction of the three systems. The network diagram composed of nodes and water transmission system reflects the internal logical relations among the three systems, which is the foundation of the optimal allocation model of water resources. Water resources optimal allocation models using linear programming on the basis of system analysis method, the water resources allocation system is built up according to the principle of water balance each control node in the network diagram, the reservoir, such as cell balance equation and constraint equation, the maximum (or minimum) objective function, through repeated iteration decision to the optimal value, as a social economic system and ecological system of water resource demand reference results.

The optimal allocation of water resources must strictly control the consumption of living and producing water outside the river in the water resources area of the basin not to exceed the available water resources [10]. In the analysis and calculation of the balance between supply and demand of water resources, information such as water quality type, groundwater quality type and the upper limit of groundwater recoverable, etc. transmitted by the water quality simulation model and the groundwater numerical simulation model should be used to 
carry out water supply by quality classification and limit the over-exploitation of groundwater. The water resource supply and demand balance analysis and water consumption balance analysis are the basis of model parameter calibration, and the water supply and demand balance analysis and water consumption balance analysis of the planning level year are carried out by establishing the water consumption relationship between the base year and the planning level year [11].

\subsubsection{Water Quality Simulation Model System Based on Optimal Allocation of Water Resources}

Based on the water quality simulation model system of optimal allocation of water resources, the long series of results of river water transmission simulated by the model of optimal allocation of water resources are taken as the known water quantity process of water quality simulation analysis and calculation. The drainage line of calculation unit and its water quantity process are pollutant load discharge channels and generated sewage process. According to the actual water consumption of "three generation", the pollutant load and discharge amount generated by nominal precipitation, the calculation unit as the pollutant load source, and the drainage line as the pollutant discharge channel, the water quality simulation calculation of the pollutant load is carried out according to the known water quantity process of each river reach. The results of water quality simulation calculation include the total amount of pollutant load, concentration, water quality type and whether the water quality target of water function area meets the standard [12].

Water quality simulation model based on optimal allocation of water resources needs to be used in conjunction with optimal allocation of water resources model. Firstly, according to the actual water quality status of each node, the initial water quality type is drawn up, and the water quantity process of the connecting line of river and drainage is calculated by the water resource optimal allocation model, and then the water quality type of each node is calculated by the water quality simulation model. Then, the difference between the calculated node water quality type and the initial proposed node water quality type is compared. If it is the same, the calculated node water quality type is replaced by the initial node water quality type to be recalculated until the water quality type of the two nodes is the same.

The water quality type of each node determined by the water quality simulation model should be consistent with the water function regionalization. If some nodes are not consistent, on the one hand, the reason is that the input parameters of the water quality model have some problems. On the other hand, because of the large amount of sewage, the sewage treatment plan should be adjusted to reduce the amount of sewage or raise the standard of sewage treatment. In a word, water quality simulation model, water function zoning results, water resource supply and demand balance and water consumption balance model need to go through several times of information feedback, in order to finally determine the water quality type of each node, to achieve the classification of water 
supply.

\subsection{Evaluation Method of Water Resource Allocation Scheme}

\subsubsection{Overview}

Evaluation of water resources optimal allocation scheme is a pointer to basin or a specific area, with social and economic, ecological environment, the harmonious development of water resources system as the foundation, analysis and calculation of the water quality and water quantity using joint configuration model, generates a series of water resources allocation scheme set (not pareto solutions), and then by the decision makers through evaluation model to determine the best recommendation.

The problem of water resource is a complex system problem involving social economy, ecological environment and water resource system. Water resources have dual properties of water quantity and water quality, that is, water resources should meet the requirements of social economic system and ecological environment system in terms of water quantity and water quality. With the development of social economy, water consumption in all industries has increased, and waste water discharge has increased. Water environment problems have become prominent, and the contradiction between water use in social economy and water use in ecological environment has become more and more prominent, which has brought new challenges to water resource allocation. On the basis of sustainable utilization of water resources, optimal allocation of water resources is to reasonably allocate various available water sources in the region or among water departments through joint allocation of water quantity and water quality and pollution intercession measures, so as to meet the social and economic water use and achieve the water quality goal of water functional areas.

The decision of optimal allocation of water resources is an important part of water resources planning. Scientific allocation decision plays a decisive role in the choice of water resources planning scheme. Through the analysis and calculation of water resources optimal allocation model, water quality simulation model based on optimal allocation of water resources and groundwater numerical simulation model, a series of optimal allocation scheme sets of water resources are determined. Because the model system has great advantages in considering quantitative indicators and factors, and has high accuracy in calculation and analysis, but without considering and analyzing qualitative factors, the decision scheme is difficult to be accepted and applied by decision makers and departments. In order to provide a scientific basis for decision makers or decision-making bodies, it is necessary to establish a unified scale for evaluating and measuring various schemes after analyzing and determining the optimal allocation scheme of water resources, namely the so-called evaluation index system. Evaluation indicators should consider and reflect all aspects of factors scientifically, objectively and as comprehensively as possible, including all the influencing factors of each program and its effects and interests, so as to compare and 
evaluate various programs and select the configuration program with the best overall effect.

\subsubsection{Scheme Evaluation Process}

The evaluation process of optimal water resource allocation scheme includes:

1) Determine the evaluation target and evaluation object system, that is, generate the optimal allocation scheme set of water resources.

2) Establish an evaluation index system. The optimal allocation of water resources involves many aspects such as society, economy, ecology and environment, etc., with many influencing factors, it is a complex giant system problem. When establishing the evaluation index system, it is necessary to construct the hierarchical structure model of evaluation index.

3) Quantitative evaluation index.

4) Dimensionless evaluation index (standardization).

5) Establish an evaluation model.

6) The evaluation index of the evaluation object is substituted into the evaluation model to obtain the comprehensive evaluation index value of each evaluation object, based on which the evaluation object is classified and sorted on the whole.

7) Feedback and control.

\subsubsection{Establishment of Evaluation Index System}

1) Establish the hierarchical structure model

For a specific water resource decision problem, the objective, influencing factors and interrelation of the decision should be clarified first. According to the category and dominant relationship of each factor, it is divided into target layer, criterion layer, index layer and program layer. Among them, the target layer is at the top, which is mainly used to identify the treatment of the relationship between the optimal water resource allocation scheme and the water resource allocation process based on the complex ecological environment, and comprehensively reflect the advantages and disadvantages of the allocation scheme. The criterion layer is in the middle layer, which further describes the internal coordination of optimal water resource allocation scheme and is the standard to measure whether the target can be achieved. The indicator layer, located at the lowest level, is a specific indicator reflecting the treatment of optimal allocation of water resources in terms of social economy, ecological environment and water resources system. The solution layer is a specific alternative.

2) Evaluation index screening

In order to eliminate or avoid the unilateral influence of subjective and objective existence as much as possible, the evaluation indexes were selected by combining expert judgment, entropy method and correlation method.

3) To determine the evaluation index system

Through the above methods, the importance degree and correlation degree of each index are analyzed, and some evaluation indexes with low importance and 
large correlation coefficient are removed to eliminate the influence of redundancy and information repetition of evaluation indexes on evaluation results. Corresponding sub-criteria level, through comprehensive analysis to determine the corresponding evaluation indicators, including the socio-economic rationality of the water shortage rate of the basin or region, new water conservancy project investment; the rationality of ecological environment includes the rate of water functional area reaching the standard and the proportion of ecological water. The rationality of water resources system includes three indexes, namely, the amount of water resources per capita, the utilization rate of water resources development, and the water consumption of ten thousand yuan of GDP (Table 2 Evaluation index system Table).

\subsection{Analysis of Optimal Water Resource Allocation Scheme in the Base Year}

1) Supply-demand balance analysis. In the current situation of social and economic development level, water level and water level, and so on and so forth, deduct the unreasonable water supply, such as overexploitation, diverted the river ecological environment water consumption, etc., and supply and demand balance of water resources analysis and calculation, determine the basin water shortage situation and their distribution, for water saving, pollution, and the salt and the implementation of regional water resources allocation to provide decision-making basis.

2) Analysis of socio-economic water consumption. Analyze the situation and direction of water consumption in different regions. It provides a reliable scientific basis for the adjustment of industrial structure, reduction of child consumption, improvement of water use efficiency, and control of social and economic water consumption within a moderate range in the future social and economic development.

3) Ecological water proportion analysis. Based on the water consumption balance estimation in the base year, the relationship between the proportion of social and economic water consumption and the proportion of ecological water consumption in the basin is analyzed to judge whether the social and economic water use occupies the ecological water, whether the amount of water entering

Table 2. Evaluation index system table.

\begin{tabular}{|c|c|c|}
\hline \multirow{5}{*}{$\begin{array}{l}\text { Optimal allocation } \\
\text { of water resources } \\
\text { in the basin }\end{array}$} & $\begin{array}{l}\text { Socioeconomic } \\
\text { rationality }\end{array}$ & $\begin{array}{l}\text { Rate of water shortage } \\
\text { Increased investment in water conservancy projects }\end{array}$ \\
\hline & $\begin{array}{l}\text { Ecological } \\
\text { environmental } \\
\text { rationality }\end{array}$ & $\begin{array}{l}\text { Water functional area compliance rate } \\
\text { Proportion of ecological water use }\end{array}$ \\
\hline & & Water resources per capita \\
\hline & $\begin{array}{c}\text { Rationality of water } \\
\text { resource system }\end{array}$ & Degree of development and utilization of water resources \\
\hline & & Ten thousand yuan of GDP consumes water \\
\hline
\end{tabular}


the sea meets the requirements of estuaries, and whether the ecological environment system of the basin meets the requirements of sustainable development.

4) Water quality standard analysis of water function area. Through the analysis of water quality standards in water functional areas, the water pollutant status and water environment status in the baseline year were evaluated, so as to provide reference for further ecological restoration and water pollution pollution control in river courses.

\subsubsection{Analysis of Socio-Economic Water Consumption}

The water consumption level, water consumption structure and regional differences of living, industry and agriculture in the base year reflect the characteristics of social and economic development in the basin. By analyzing the consumption direction of water resources in social economy, this paper provides a reliable technical basis for the adjustment of industrial structure, reduction of child consumption, improvement of water use efficiency and control of water consumption in social economy in the course of future social economy development. The analysis and calculation show that when the water quality is poor, the water consumption structure of divided water supply and non-divided water supply is different to some extent, but the water consumption rate basically remains unchanged, because the water shortage of water-quality type occupies a small share. The water consumption results of Wenchuan, Li county, MAO County, Heishui County and Songpan County in the upper reaches of Minjiang river are selected as samples (Table 3, Table 4).

It can be seen from Table 3 and Table 4 that the total water consumption of Maoxian county is the highest in 2008, that of Wenchuan County is 15.93 million cubic meters, and that of Li County is the lowest in 9.96 million cubic meters. Shigeru seemed to manage three county irrigation water consumption are more than $70 \%$ of the total water consumption, urban public water consumption, ecological environment water and industrial water consumption ratio is extremely

Table 3. Water consumption of five counties in the upper Minjiang River in 2016.

\begin{tabular}{|c|c|c|c|c|c|c|c|c|c|c|}
\hline \multirow{3}{*}{$\begin{array}{c}\text { Administrative } \\
\text { district at county } \\
\text { level }\end{array}$} & \multicolumn{8}{|c|}{ Agricultural water consumption } & \multirow{2}{*}{\multicolumn{2}{|c|}{$\begin{array}{l}\text { Industrial water consumption } \\
\text { Non-fire (nuclear) electricity }\end{array}$}} \\
\hline & \multicolumn{2}{|c|}{ Plow land } & \multicolumn{2}{|c|}{$\begin{array}{c}\text { Forestry, animal } \\
\text { husbandry and fishery }\end{array}$} & \multicolumn{2}{|c|}{ livestock } & \multicolumn{2}{|c|}{ subtotal } & & \\
\hline & 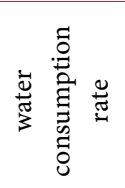 & 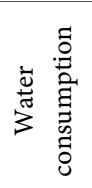 & 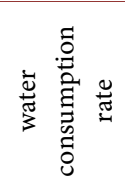 & 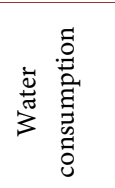 & 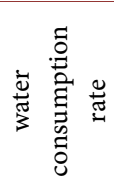 & 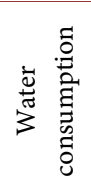 & 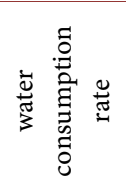 & 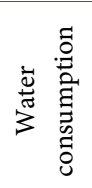 & 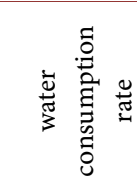 & 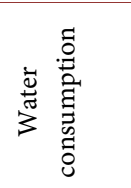 \\
\hline Wenchuan & 81 & 1104 & 83 & 95 & & & 81 & 1199 & 41 & 128 \\
\hline Lixian & 81 & 739 & & & & & 81 & 739 & 41 & 137 \\
\hline Maoxian & 81 & 1592 & & & & & 81 & 1592 & 41 & 133 \\
\hline Songpan & 81 & 789 & 83 & 33 & 92 & 193 & 83 & 1015 & 41 & 116 \\
\hline Heishui & 81 & 595 & 83 & 29 & 92 & 39 & 82 & 662 & & \\
\hline
\end{tabular}


low, that the region is given priority to with the first industry, urbanization rate needs to be improved, economic development, sewage emission, improve the ecological environment is an issue in the future should focus on, agricultural water saving has certain potential in the future.

\subsubsection{Ecological Water Proportion Analysis}

Ecological water use refers to the amount of water remaining after deducting social and economic water consumption, which should be estimated through the water balance analysis of water resources in the basin. The water balance analysis of water resources in different zones involves agricultural water consumption, industrial water consumption, urban public water consumption, residential water consumption, ecological environment water consumption, etc.

As can be seen from Table 5 and Table 6, the total water consumption in MAO County is the highest at 27.15 million cubic meters, that in Wenchuan County is 21.98 million cubic meters, and that in Li County is the lowest at 14.45 million cubic meters. Among them, the ecological water consumption of Maoxian county is 10,000 cubic meters, that of Wenchuan County is 10,000 cubic meters,

Table 4. Water consumption of five counties in the upper Minjiang River in 2016.

\begin{tabular}{|c|c|c|c|c|c|c|c|c|c|c|c|c|}
\hline \multirow{3}{*}{ county } & \multicolumn{4}{|c|}{ Urban public water consumption } & \multicolumn{4}{|c|}{ The water consumption of residents } & \multirow{2}{*}{\multicolumn{2}{|c|}{$\begin{array}{c}\text { The ecological environment } \\
\text { consumes water }\end{array}$}} & \multicolumn{2}{|c|}{$\begin{array}{l}\text { The total water } \\
\text { consumption }\end{array}$} \\
\hline & \multicolumn{2}{|c|}{$\begin{array}{l}\text { The construction } \\
\text { industry }\end{array}$} & \multicolumn{2}{|c|}{ Service industry } & \multicolumn{2}{|c|}{ urban } & \multicolumn{2}{|c|}{ rural } & & & \multirow{2}{*}{ 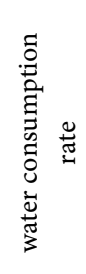 } & \multirow{2}{*}{ 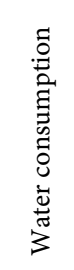 } \\
\hline & 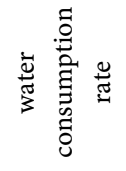 & 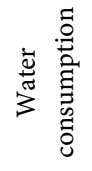 & 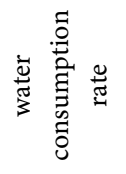 & 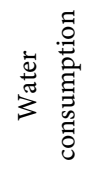 & 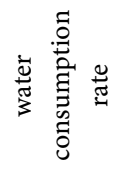 & 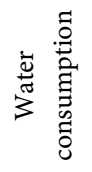 & 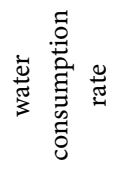 & 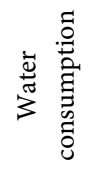 & 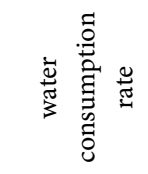 & 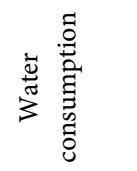 & & \\
\hline Wenchuan & & & 14 & 6 & 7 & 13 & 87 & 247 & 66 & 1 & 69 & 1593 \\
\hline Lixian & & & 14 & 1 & 7 & 4 & 87 & 112 & 66 & 3 & 69 & 996 \\
\hline Maoxian & & & & & 7 & 8 & 87 & 274 & 66 & 1 & 74 & 2008 \\
\hline Songpan & 33 & 1 & 14 & 7 & 7 & 6 & 87 & 244 & 66 & 3 & 72 & 1394 \\
\hline Heishui & 33 & 3 & 14 & 7 & 7 & 8 & 87 & 326 & 66 & 27 & 74 & 1033 \\
\hline
\end{tabular}

Table 5. Water consumption (part) of five counties in the upper Minjiang River in 2016.

\begin{tabular}{|c|c|c|c|c|c|c|c|c|c|c|}
\hline \multirow{3}{*}{ county } & \multicolumn{7}{|c|}{ Agricultural water consumption } & \multicolumn{3}{|c|}{ Industrial water consumption } \\
\hline & \multicolumn{3}{|c|}{ Agricultural irrigation } & \multirow{2}{*}{$\begin{array}{l}\text { Fishing pond } \\
\text { filling water }\end{array}$} & \multirow{2}{*}{$\begin{array}{l}\text { Livestock } \\
\text { water }\end{array}$} & \multirow{2}{*}{ subtotal } & \multirow{2}{*}{$\begin{array}{c}\text { Ground } \\
\text { water }\end{array}$} & \multirow{2}{*}{$\begin{array}{c}\text { fire } \\
\text { (nuclear) } \\
\text { electricity }\end{array}$} & \multirow{2}{*}{$\begin{array}{l}\text { Non-fire } \\
\text { (nuclear) } \\
\text { electricity }\end{array}$} & \multirow{2}{*}{ subtotal Groundwater } \\
\hline & Arable lan & oodland garden & rassland & & & & & & & \\
\hline Wenchuan & 1363 & & & 115 & & 1478 & & & 311 & 311 \\
\hline Lixian & 912 & & & & & 912 & & & 335 & 335 \\
\hline Maoxian & 1966 & & & & & 1966 & & & 325 & 325 \\
\hline Songpan & 974 & 30 & 10 & & 210 & 1224 & & & 283 & 283 \\
\hline Heishui & 734 & 35 & & & 42 & 811 & & & & 0 \\
\hline
\end{tabular}


Table 6. Water consumption (part) of five counties in the upper Minjiang River in 2016.

\begin{tabular}{|c|c|c|c|c|c|c|c|c|c|c|c|c|c|c|}
\hline \multirow[b]{2}{*}{ county } & \multicolumn{4}{|c|}{ Urban public water consumption } & \multicolumn{4}{|c|}{ The water consumption of residents } & \multicolumn{4}{|c|}{$\begin{array}{l}\text { The ecological environment } \\
\text { consumes water }\end{array}$} & \multicolumn{2}{|c|}{$\begin{array}{l}\text { The total water } \\
\text { consumption }\end{array}$} \\
\hline & 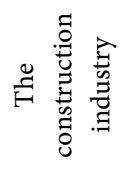 & 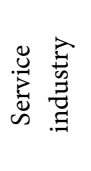 & 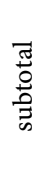 & 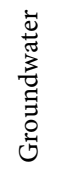 & : & 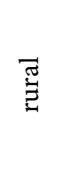 & 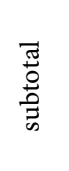 & 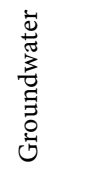 & 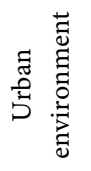 & 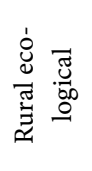 & $\begin{array}{l}\vec{\pi} \\
0 \\
0 \\
0 \\
0\end{array}$ & 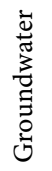 & $\begin{array}{l}\text { तే } \\
\stackrel{0}{0}\end{array}$ & 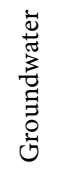 \\
\hline Wenchuan & & 40 & 40 & & 184 & 284 & 468 & 13 & 1 & & 1 & & 2298 & 13 \\
\hline Lixian & & 5 & 5 & & 59 & 129 & 188 & 104 & 5 & & 5 & & 1445 & 104 \\
\hline Maoxian & & & 0 & & 108 & 315 & 423 & 182 & 1 & & 1 & & 2715 & 182 \\
\hline Songpan & 4 & 50 & 54 & & 92 & 281 & 373 & 19 & 5 & & 5 & & 1939 & 19 \\
\hline Heishui & 8 & 50 & 58 & & 117 & 375 & 491 & 3 & 41 & & 41 & & 1401 & 3 \\
\hline
\end{tabular}

and that of Li County is 50,000 cubic meters, indicating that Li County has a high proportion of ecological water consumption, which is conducive to the healthy development of social economy and ecological environment. As the proportion of industrial water consumption is relatively high in some regions, the relationship between industrial water consumption and ecological water consumption should be coordinated in the planning level year, so as to ensure moderate ecological water demand and promote the harmonious development between man and nature.

\section{Implementation Guarantee and Countermeasures for Optimal Allocation and Comprehensive Utilization of Water Resources in the Upper Minjiang River Basin}

\subsection{Policy and Regulation Guarantee}

\subsubsection{Improve Local Regulations Related to Water Affairs}

The people's governments of Aba Prefecture and county, where the upper reaches of the Minjiang River are located, should attach great importance to the legislative work related to water affairs, accelerate the construction of the water affairs legal system, vigorously promote the comprehensive law enforcement of water affairs, improve the law enforcement capacity and level, and comprehensively promote the water control in accordance with the law. To make water affairs have rules to follow and laws to follow [12]. Some of these regulations and rules have been promulgated and implemented for many years and are no longer suitable for the current situation. Therefore, they should be revised or reformulated in a timely manner and the local regulations system related to water affairs should be further improved.

\subsubsection{Strengthen Industrial Layout Guidance}

The layout of industrial structure and the scale of urban and industrial development in the upper Minjiang River basin should be matched with the conditions of water resources and water supply infrastructure. Through policy guidance and various incentive measures, according to the development and changes of re- 
gional planning, water conservancy projects that are beneficial to economic distribution and reasonable ways of increasing revenue and reducing expenditure are optimized to make the industrial distribution adapt to the pattern of water resources allocation. The development of industries and tertiary industries with low energy consumption and pollution should be encouraged in areas with low river capacity. The existing industries should be technically reformed to improve the water circulation rate and reduce pollution discharge. Improve the level of sewage treatment and reduce the discharge of pollutants in accordance with the requirements of total water function area control.

\subsubsection{Improve Water-Saving and Pollution Control Policies}

To carry out the Water Law of the People's Republic of China, the Law of the People's Republic of China on Soil and Water Conservation, the Law of the People's Republic of China on The Prevention and Control of Water Pollution and the Regulations of Sichuan Province on the Administration of Water Conservation. We will accelerate the construction of laws and regulations for a water-conserving society, and bring water conservation and pollution control into the legal and standardized track [13]. In accordance with the requirements of the outline of the national plan for building a water-conserving society and the plans for the social and economic development of provinces and prefectural governments, the standards for building a water-conserving society in the river basin shall be formulated, the objectives of the plan shall be clarified, the responsibilities shall be fulfilled, and the sound development of building a water-conserving society shall be promoted.

\subsubsection{Establish a Reasonable Water Price System}

A reasonable water price mechanism should be established, and a reasonable water price should be set according to the principles of compensation cost, reasonable income, water conservation and fair burden, which should not only ensure the safe operation of the river basin, but also consider the bearing capacity of water-using farmers (residents). We will accelerate the reform of water prices. First, we will vigorously implement the system of progressive markup exceeding quotas. Basic water prices shall be applied within the quota, and different water prices shall be applied for the excess part at different levels; Second, we will promote the "two-part" water price system that combines basic and measured water prices to promote the rational distribution of water resources and the sustainable operation of projects to improve people's livelihood [14]. The third is to implement seasonal water price or seasonal floating water price according to local conditions to promote water users to adjust the water structure and crop planting structure; Fourth, the "terminal water price" system will be implemented, eliminating intermediate links and charging directly to households.

\subsection{Water Resources Management Guarantee}

\subsubsection{Build an Integrated Water Affairs Management Platform}

We will deepen the reform of the water resources management system and es- 
tablish a unified water resources management system that conforms to the laws of nature and the laws of economic and social development, so as to provide institutional guarantee for the smooth implementation of the comprehensive water resources planning on schedule. To implement unified management, planning and dispatching of water resources; Unified management of surface and groundwater, water and water quality, urban and rural water resources within the region, and distribution of water rights in urban and rural areas and industries; Consider various functions of water as a whole, plan the whole process of water storage, water supply, water use, water-saving, drainage, sewage treatment and reuse of reclaimed water, and allocate water resources scientifically; Management covers the development, utilization, management, allocation, conservation, protection and other fields of water resources [3].

\subsubsection{Ensure the Optimal Allocation Pattern of Water Resources}

Formulate standards for the implementation of water resources allocation plans and relevant supporting systems to ensure the implementation of optimal water resources allocation plans. Promote market-oriented water resources allocation system, increase revenue and reduce expenditure, and realize efficient water distribution under the premise of water use equity.

A modern water rights management system should be established to realize the conversion of water rights and the trading of water rights on the basis of clarifying water rights, so as to maximize the benefits of water resources. We will build a water-conserving society, combine water conservation with water resources protection, and improve the efficiency of water resources utilization. We will carry out diversified projects to build water sources, increase the scale of reclaimed water utilization, and alleviate the pressure of water supply and demand.

\subsubsection{Strengthen the Information Construction of Water Resources}

Scientific, sound management and high-quality planning require the support of basic data. It is necessary to monitor the condition of water resources in a timely manner and master the carrying capacity of water resources in a comprehensive and dynamic manner. Using " $3 \mathrm{~s}$ ” technology of water regime, rainfall regime, drought and flood disasters, water quantity, water quality, water environment, water engineering of water conservancy information acquisition, storage, sorting, analysis, to strengthen and improve the source of drinking water, water function area of monitoring station network construction, the outlet of hydrology, water quality, for the river basin of the upper reaches of Minjiang river water resources management, supervision, provide technical support and disaster assessment.

\subsection{Countermeasures and Suggestions}

\subsubsection{Strengthen Organizational Leadership and Implement Target Responsibility}

The people's governments of Aba Prefecture and five counties, where the upper 
Minjiang River basin is located, are the main bodies of responsibility for the management of water resources in the basin. It is necessary to take optimal allocation and comprehensive utilization of water resources as the priority areas for the economic and social development of the basin, earnestly strengthen organization and leadership, and incorporate the management of water resources into the term work goals of the prefecture and county governments. People's governments at all levels and relevant departments shall, in accordance with the relevant requirements for the utilization and management of water resources, break down and refine the objectives and tasks of the stages under the strictest water resources management system, define the division of responsibilities, refine work plans, rationally allocate resources and accelerate the coordinated development of the economy, society and ecology of the river basin. We have established a system of accountability for targets and an assessment system for officials, implemented target responsibility at all levels, and implemented a strict accountability system. The competent administrative departments of water resources administration shall earnestly perform their duties and do a good job in the management and utilization of water resources.

\subsubsection{Increase Investment and Optimize Investment Structure}

Hold on to both hands. Adhere to coordinated government function and market mechanism, strengthen the basic configuration of water resources and comprehensive utilization of the government leading role, give full play to the decisive role of market resources, reform the innovation system mechanism, integrate various resources, concentrated efforts, through fiscal, financial, taxation, price policy, such as promoting sound and rapid development of water resource utilization. It is necessary to strengthen the use and management of water resources project funds, improve the financial management system, ensure the safety of funds, and improve the efficiency of investment.

\subsubsection{Improve the Consultation Mechanism and Promote Public Participation}

Accelerating the optimal allocation and comprehensive utilization of water resources not only needs the strong promotion of people's governments at all levels and relevant departments, but also needs the support and participation of the whole society. Development and reform, finance, water, land and resources, environmental protection, poverty alleviation immigration and other related departments to the two levels of people's government under the unified leadership of the state county, according to the division of responsibilities, strengthen communication and coordination, close cooperation, mix, earnestly implement good water resources project investment, project examination and approval, use pre-examination, environmental impact assessment, resettlement and other related work, the implementation of the water resources planning is used to determine the various tasks. In order to create a favorable social environment for the full utilization and protection of water resources, the publicity for the protection and utilization of water resources should be intensified and the aware- 
ness of water crisis and the concept of water law should be raised [15]. We will continue to make government affairs more open, strengthen administrative oversight, increase transparency and public participation in the protection and use of water resources, and actively promote public participation.

\subsubsection{Implement the Demarcation of "Red Line" and Strictly Manage Efficiency}

Implement the red line of water resources development and utilization, and strengthen the allocation and management of water resources; Implement the wUE red line and strictly manage the efficiency; We will implement the red line for limiting pollution in water function areas and strengthen water resources protection. Organization to promote according to river basin area of the upper reaches of Minjiang River water withdrawal control indicators and industry water use quotas for water application for examination and approval, strict water resources argumentation and the supervision and administration of water and gradually establish a accords with the practice of Minjiang River basin water use efficiency of monitoring the inspection, supervision and administration system, promote all walks of life for water use of new technologies, new methods, new equipment water reducing, containing extensive use of water.

\subsubsection{Make Overall Arrangements for Water Resources and Rationally Distribute Industries}

Basin of the upper reaches of Minjiang River while fully considering the spatiotemporal distribution of water resources from the boundary between administrative districts and departments segmentation and full analysis of the existing water resources, combines the condition of regional planning, reasonable planning and layout and construction of large and medium-sized water conservancy projects, combined with the distribution of other natural resources, consider as a whole from the Angle of regional industrial layout and adjustment, high water consumption of industrial water shortage city not blind development, water resources shortage region carefully choose industry system, form a reasonable industrial structure, reasonable construction to adjust the imbalance of water combination is the rational allocation of regional water resources.

\subsubsection{Improve the Monitoring System and Improve the Supervision Ability}

It is necessary to conduct regular monitoring of key water areas and important sections, implement monitoring teams, improve monitoring equipment and means, and clarify monitoring tasks. In particular, the water quality and water quantity monitoring capacity of provincial boundary sections should be strengthened, and the monitoring system corresponding to the water resources development and utilization control red line, water efficiency control red line, and water functional area limit pollution carrying red line management should be improved. We will strengthen the construction of facilities for metering and monitoring water withdrawals by households and for monitoring and controlling the discharge of sewage in human rivers, and comprehensively improve our 
ability to supervise and control water resources.

\section{Conclusion}

In this paper, the natural environmental conditions of water resources and the characteristics of water resources system in the upper reaches of the Minjiang River are analyzed and studied, and the optimal allocation scheme and analysis of water resources in the upper reaches of the Minjiang River are put forward. Finally, relevant countermeasures and suggestions are put forward according to the existing problems of water resources in the upper reaches of the Minjiang River. At present, there are relatively few relevant studies on water resources in China. However, water resources are an inseparable element of our life and social development. How to develop, utilize and protect water resources will be a far-reaching and long-term and indispensable important topic.

\section{Acknowledgements}

This study was awarded the Graduate Innovation Project of Southwest University for nationalities (No. CX2019SZ02) support.

\section{Conflicts of Interest}

The author declares no conflicts of interest regarding the publication of this paper.

\section{References}

[1] Wang, M.-L., Guo, L.-J. Gao, P.-Y. and Fu, H. (2006) Water Resources Security and Adaptation Countermeasures in the Shanmin River Basin. Journal of Chongqing Jiaotong University, 25, 138-141.

[2] Xu, Z.L. (1992) Environmental Geology. Qingdao Ocean University Press, Qingdao.

[3] Liu, H. (2000) Principles and Guarantee Conditions for Sustainable Utilization of Water Resources. China Water Resources, No. 8, 51-53.

[4] Chen, J.-Q. (1996) Global Change and Sustainable Development of Water Resources. Progress in Water Science, 7, 187-192.

[5] Li, L.Y. (2000) On the Concept of Rational Allocation and Carrying Capacity of Water Resources. Progress in Water Science, 11, 307 313. (In Chinese)

[6] Ding, H.R., Yi, C.B., Huang, X.H., et al. (2007) Current Situation and Sustainable Utilization of Water Resources in the Upper Reaches of Minjiang River. Science and Technology Management of Land Resources, No. 3, 66-69.

[7] Cohen, J.E. (1997) Population, Economics, Environmental and Culture: An Introduction to Human Carrying Capacity. Journal of Applied Ecology, 34, 1325-1333. https://doi.org/10.2307/2405250

[8] Seyam, I.M. and Hoekstra, A.Y. (2000) The Water Value-Flow Concept. Technische Universities Delft, Delft.

[9] Zhang, H.P., Zhang, H.B., Yang, N., Zhang, Y.Q. and Meng, H. (2004) Gis-Based Preliminary Analysis of Geomorphology in the Upper Reaches of Minjiang River. Chinese Journal of Geological Disasters and Prevention, 15, 116-119.

[10] Wan, X.N., Liu, D. and Cai, J.S. (2004) Quality Evaluation System of "Ecoenvironmental 
Geology" in the Upper Reaches of Minjiang River. Progress in Earth Science, No. S1, 477-481.

[11] CAI, J.s. (2004) Evaluation and Sustainable Development of Ecological Environment Geology in the Upper Reaches of Minjiang River. Master Thesis, Chengdu University of Technology, Chengdu.

[12] Meng, G.C., Ma, D.T., et al. (2007) Environmental Problems and Their Driving Forces in the Upper Reaches of the Minjiang River. Arid Region Geography, 30, 758-764.

[13] Zhang, W.G., Hu, Y.N., Zhang, J., et al. (2007) Changes in Water Conservation and Value of Forest Ecosystem in the Upper Reaches of Minjiang River in Recent 30 Years. Journal of Ecology, 26, 1063-1067.

[14] Xu, J.M. (2006) Research on Water Resources Carrying Capacity in the Upper Reaches of Minjiang River. Master Thesis, Sichuan University, Chengdu.

[15] Liu, L.J. (2005) Application of MTCLIM Model in Climate Simulation of the Upper Reaches of Minjiang River. Resources and Environment of the Yangtze River Basin, 14, 248-253. 